\title{
MAKING SENSE OF RUSSIAN IMPERIALISM: WARFARE, DOMESTIC REFORM, AND ABSOLUTISM, 1700-1856

\author{
Onur İşçi*
}

\begin{abstract}
$\ddot{\mathbf{O z}}$
Rus Emperyalizmini Anlamlandırmak: Savaş, Islahat, ve Mutlakiyet, 1700-1856

Emperyalizmi tanımlamaya çalışan tarihçiler genellikle savaşlar ve müteakip ıslahatlar arasında bir bağlantı kurarlar. $\mathrm{Bu}$ makale yeni ve eski tarih yazımından faydalanarak Rusya İmpatorluğu'nda 1slahatlara yol açan üç önemli savaşı inceleyecektir: Büyük Kuzey Savaşı (17001721), 1768-74 Rus-Osmanlı Savaşı, ve Kırım Savaşı (1853-1856). Esas itibariyle bu çalışmanın amacı batılı akademisyenler arasında yaygın olan ve Rusya'nın kuruluşundan beri iç siyasi kaygılardan bağımsız olarak ve kontrolsüz biçimde genişleyerek dünyaya egemenlik kurmaya çalıştığına yönelik iddiaları tartışmaktır. Burada hedeflenen sonuç kapsayıcı ve bütünsel bir hükme varmak değil, Rusya'da imparatorluk yönetimine dair esasları çağdaş müverrihlerin ve 19. asrın önemli Rus akademisyenlerinin tartışmaları ışı̆̆ında irdelemek olacaktır.
\end{abstract}

Anahtar Kelimeler: Rus Emperyalizmi, Dış ve İç Siyaset Bağlantısı, Büyük Kuzey Savaşı, 176874 Rus-Osmanlı Savaşı, Kırım Savaşı.

\begin{abstract}
Historians often establish a link between wars and ensuing domestic reforms when defining imperialism. Drawing on older and newer historiography, this paper evaluates the importance three major wars in Russian history that precipitated internal reform: The Great Northern War (1700-1721), the Russo-Turkish War of 1768-74, and the Crimean War (1853-1856). Ultimately, this paper seeks to eschew a widespread misperception amongst specialized Western academics that the Russians have always had an unrestrained drive to expand and dominate the world, regardless of domestic considerations, dynastic or otherwise. The point is not to make an overarching and holistic judgment, but to draw in the arguments made by historians (including major $19^{\text {th }}$-century historians of Russia) and make conclusions concerning the concrete mechanisms of imperial governance in Russia.
\end{abstract}

Key Words: Russian Imperialism, Interaction of Foreign and Domestic Policy, The Great Northern War, The Russo-Turkish War of 1768-1774, Crimean War.

\footnotetext{
* Yrd. Doç. Dr., Bilkent Üniversitesi, İktisadi, İdari ve Sosyal Bilimler Fakültesi, Uluslararas1 İlişkiler Bölümü, Ankara. E-mail: onur.isci@bilkent.edu.tr
} 
"Although Great Peter has been snatched from our vision, he remains nevertheless always present in our hearts."

M. V. Lomonosov ${ }^{1}$

In the perplexing world of historical jargon, defining "imperialism" as an overarching concept is a difficult enterprise. But when the term is applied to Russia - a country that has always appeared somewhat eerie and too colossal to its neighbors - the problem becomes less challenging. For instance, ever since Russia's reannexation of Crimea in 2014, Vladimir Putin's foreign policy has been exclusively described as imperialistic. There is a more or less established notion amongst western observers that Russia has consistently posed a threat to the balance of power in Europe as it has to the sovereignty of neighbors around its vast territory. It is often argued that, despite its gargantuan size on the map, Russia inexorably pushed its borders outward. As Henry Kissinger once put it, "paradox was Russia's most distinguishing feature... constantly at war and expanding in every direction, it nevertheless considered itself permanently threatened."

True as this statement may be, analysts and Moscow observers have a tendency to ignore the peculiar ways in which contours of Russian foreign policy were forged in its formative period, roughly between 1700s and 1850s. Understanding the interaction between Russia's foreign and domestic concerns, as well as major patterns of continuum between imperial and contemporary Russia, requires a careful reading of the Russian sonderweg (special path) to imperial governance in its proper historical context. In the period between the Petrine revolutions (1700-1725) and the second half of the $19^{\text {th }}$ century, as the Russian Empire incorporated new non-Russian peoples into their domains through numerous wars, redefining absolutism through domestic reforms became more of a necessity than prestige for the House of Romanov.

A quick survey of imperial Russian history would reveal two quintessential fault lines in existing historiography. The first one is Alexander Gorbatyi-Shuisky's siege and conquest of Kazan (1552-56), which enabled Tsar Ivan IV (the Terrible) incorporate Safa Giray's Tatar Khanate into his domain and subsequently bring Russia's first non-Orthodox population under control through the Nogais. This event marked the emergence of the Tsardom of Rus'

\footnotetext{
${ }^{1}$ Lomonosov 1952, p.207.

${ }^{2}$ Kissinger 1994, p.140.
} 
as a multi-ethnic, multi-confessional, therefore in the strict sense of the word, a regional imperial power. The second fault line is the Treaty of Nystad (1721). The Great Northern War (1700-1721) manifested a radical shift in European balance of power, decisively replacing Swedish imperialism with Russia's control of Europe's northern frontier. It was after Peter the Great's successful conclusion of Russia's prolonged war with Sweden in Nystad that Russia joined the second-wave of European absolutist empires, alongside Prussia.

The military revolution that took place in Europe (1560-1660) had largely been driven by dynastic aggrandizement, creating first and foremost a new mode of conscription. ${ }^{3}$ This stage was not reached in Prussia before the end of the century, and in Russia until Peter's military reforms. In fact, few European monarchs of the sixteenth and seventeenth centuries were prepared to establish national armies; since most of them probably agreed with Christian IV of Denmark and John George of Saxony in having second thoughts about arming the lower orders. As Michael Roberts suggests, "only where the peasantry had been reduced to a real serfdom was it esteemed safe to proceed upon the basis of conscription." ${ }^{4}$ In a similar vein, Dominic Lieven argues that the key obstruction to maximizing the effectiveness of European absolutist militaryfiscal states was the disparate territorial and corporate institutions and privileges inherited from the feudal era. ${ }^{5}$ Luckily for the Muscovite state, by the end of the seventeenth century, feudal residues of this sort had already been uprooted by tsars in earlier centuries, particularly in their Europe frontiers. Moreover, Russia was not burdened by anachronistic fiscal and administrative institutions, and the vested interests, which grew around them. Even though, Russia was at least half a century behind its European rivals, the circumstances under which Peter embarked on his odyssey were certainly more favorable.

\section{Petrine Imperialism in Russian Historiography}

At the turn of the eighteenth century it became clear that the central condition for maintaining sustainable human and economic resources and for providing strategic security against similar ambitions of one's neighbors was primarily a predatory pursuit of territorial expansion and the creation of an effective military and fiscal state apparatus. This is where the importance of the Great Northern War lies; the Treaty of Nystad in 1721 embodies the success of Peter's achievements and the coming into being of Russia as a great European

\footnotetext{
${ }^{3}$ Parker 1988, preface and introduction.

${ }^{4}$ Roberts 1995, p.13-35, here, p. 17.

${ }^{5}$ Lieven 2006, p.9-26.
} 
power. Beginning with his incipient designs for reform during the Grand Embassy (Velikoye posol'stvo) in 1697-98, Peter managed to saw together Russia like a quilt, scrap by scrap. As a result, in 1721, the Senate in St. Petersburg staged an elegant ceremony and granted a new designation to Peter I's official titles. In addition to such traditional terms as tsar and samoderzhets (autocrat), the Russian ruler would now be called imperator vse-rossiiskii (Emperor of All Russia). ${ }^{6}$

It is essential to remember that aulic (palace) titulature meant more than court formalities. Nor did Peter's novel epithet merely signify the imperial character of the Russian state, for Russia had already been an empire since 1552. In Mark Bassin's words, "what was significant, rather, was the resolution to formalize this status using the foreign Latin-based terms imperiia and imperator." The decision to draw on a Latin rather than Slavic lexicon for such an important characterization, in Bassin's view, ran parallel to "the spirit of the so-called Europeanisation project." ${ }^{7}$ This was a clear indication of the empire's sincere ambitions in recasting the Russian state from the Tsar down to an entirely new configuration. The Treaty of Nystad and the ensuing ceremony held in St Petersburg therefore vindicates the assertion that Russia will now conform to the basic contours of European absolutism.

Three instrumental books, which appeared in the last twenty years, are widely read by English speaking scholars, conjuring up different vignettes of imperial Russia's first revolutionary period. It would be fair to say that, despite their different agendas, James Cracraft's The Revolution of Peter the Great (2003); Paul Bushkovitch's Peter the Great: The Struggle for Power, 16711725 (2001); and Lindsey Hughes' Russia in the Age of Peter the Great (1998) share the same fascination with Peter I's reign. Although Cracraft's book adds little to our existing knowledge of Peter's Northern War, it is nevertheless, a succinct survey of his subsequent military-diplomatic reforms and contains useful information for an elementary reader in Russian history. The author's main argument is that Peter inherited from his royal Muscovites fluid boundaries and tense relations with both the Ottomans and the Kingdom of Poland. But Peter's struggles with these two powers - either for gaining new territories or establishing strategic buffer zones - ultimately entangled with his protracted war against Sweden. The prospect and reality of war against the Ottoman Empire, Poland and Sweden quickly led to a realization that he had to reform his armed forces. The disastrous defeat at Narva in 1700 by Swedish forces persuaded Peter that a more comprehensive reform program was

\footnotetext{
${ }^{6}$ Acar 2009, p.142-144.

${ }^{7}$ Bassin 2006, p.45-68.
} 
necessary. ${ }^{8}$ Cracraft offers a micro summary of events leading up to the foundation of the admiralty in 1696, creation of the Moscow School of Mathematics and Navigation in 1701; St Petersburg Naval Academy in 1715; promulgation of the Military Statute in 1716; and, ultimately, the promulgation of Table of Ranks and law of succession in 1724.

Lindsey Hughes' vivid and highly detailed monograph, on the other hand, provides the readers with a broader perspective and necessary background for understanding his social reforms, such as the adoption of Julian calendar in 1700; publication of the Moscow Gazette (Vedemosti) in 1703; foundation of the Senate in 1711; creation of the Russian "civil alphabet" in 1708-10; and the establishment of administrative colleges for provincial government reform in 1720. ${ }^{9}$ Bushkovitch's treatment of the first decade of the Great Northern War is particularly scrupulous. The author convincingly integrates the revolts in Astrakhan and Bulavin with the appointments to the Russian high command during the war with Sweden. Thus, he offers a new pitch on the guberniia reforms of I708-09, through analyzing them "with reference to Peter's creation of a new balance of power with the aristocracy."10

Aside from the works of Hughes, Cracraft and Bushkovitch, a fourth influential source for Russian-readers is the slightly dated edited collection by N.I. Pavlenko, L.A. Nikiforov, and M.Ia. Volkov. Published after a conference held in the Soviet Union, commemorating the tercentenary of Peter's birth, in many regards this book reiterates the established image of Peter as a strong reforming monarch, with a complex personality. Pavlenko discusses Peter's political ideas in detail, engaging with the elusive notion of 'general welfare,' which for Pavlenko, Peter used differently, roughly synonymous with the 'interest of state.' For Peter, Pavlenko argues, the state was primarily the guardian of economic and social well-being of the whole community. ${ }^{11}$ Perhaps the most striking article in this collection is by M. D. Rabinovich, who studies the officer corps under Peter. Having analyzed the careers of about eighty percent of all officers of the regular regiments in 1720-21, the author concludes that although the officers represented many social origins, descendants of the seventeenth-century nobility made up the largest group. Furthermore, Rabinovich suggests two thirds of all offices owned lands or serfs, and almost ninety percent of them were literate. Those with lower-class origins remained a considerable minority, and 22.7 percent of the soldiers came from the taxpaying

\footnotetext{
${ }^{8}$ Cracraft 2003, p.28-54.

${ }^{9}$ Hughes 1998.

${ }^{10}$ Bushkovitch 2001, p.282.

${ }^{11}$ Pavlenko 1973, p.131-171.
} 
classes of society. Rabinovich therefore suggests that Peter introduced the Table of Ranks for reward and preservation. Likewise, T.S. Maikova's study on Peter's "Gistoriya" of the Swedish War demonstrates that Peter was not simply a patron but initiator, author and editor of modern Russian historiography. ${ }^{12}$

For scholars of Petrine reforms, who hold tenures at institutions outside the English-speaking world (where a plethora of secondary literature on Peter the Great is easily accessible) such $19^{\text {th }}$ century classics as S. M. Soloviev's Istoriya Rossii s drevneishikh vremen, and his apprentice V. O. Klyuchevsky's Kurs russkoi istorii still remain as primary tools of instruction. ${ }^{13} 150$ years have elapsed since Soloviev's magnum opus first appeared, and yet his firm belief in historical laws that dictate the precedence of objective over subjective reality renders this book perhaps still more fitting in most academic traditions than more recent ones that fell into the stream of postmodern paradigm. Soloviev's Hegelian position and perception of history as a progressive and dialectic process becomes crystal clear in his full expression on the state and on the lives of great men. This last fact is most evident in his account of Peter I and his great reforms.

Notions of dynastic aggrandizement or Peter's desire to catch up with Europe's military revolution of the preceding century were anachronistic to Soloviev's narrative. Yet his discussion on the two 'warrior kings' (Charles XII and Peter I) indicates that he sees dynastic conflicts between rights of inheritance as the main motor of the Great Northern War. Perhaps what is more important and relevant to our subject in Soloviev's account is that, we can clearly see that in prosecuting the Northern War, Tsar Peter and his government had fully assimilated contemporary European political terminology and associated legal, political and diplomatic concepts. This brings us back to the conventional Westernizer-Slavophile dualism that existed among Soloviev's contemporaries.

When Soloviev was writing his manuscript, Peter was under attack from the Slavophile camp. Obviously, Slavophiles were blaming Peter for having put Russia on the wrong track toward the setting sun (the West rather than the East). A short passage from N.M. Karamzin's Memoir on Ancient and Modern Russia, would further elucidate this point. Karamzin, whose central theme was the consolidation of the autocracy and other dynastic considerations, argued that "[Peter's] goal was not only to bring new greatness to Russia, but also to accomplish the complete ${ }^{14}$ assimilation of European customs...And while

\footnotetext{
${ }^{12}$ T.S. Maikova Gistoriia Sveiskoi Voiny: Podennaia Zapiska Petra Velikogo, Krug, 2004.

${ }^{13}$ Soloviev 1962; Klyuchevsky 1918, lectures 59 through 65.

${ }^{14}$ Italics not mine, possibly Pipes's.
} 
extolling the glory of this monarch, shall we overlook the pernicious side of his brilliant reign? Let us not go into his personal vices. But his passion for foreign customs surely exceeded the bounds of reason. Peter was unable to realize that the national spirit constitutes the moral strength of states, which as indispensable to their stability as is physical might." 15 Therefore, when Klyuchevsky had read his advisor's discussion of Peter, he thought as if Soloviev was trying to defend Peter "from some unspecified assailants." 16

Consequently, Klyuchevsky's analysis of the reign of Peter the Great differs in certain respects from Soloviev's. Klyuchevsky's Kurs russkoi istorii, which is essentially a collection of his popular lectures on Russia from ancient times to the $19^{\text {th }}$ century, challenges the so-called statist school of Tsarist historians. ${ }^{17}$ Rather than focusing on the Petrine autoctacy and its role in recasting the Russian society, Klyuchevksy attributed more significance to the socio-economic and environmental factors. He is particularly attentive to the social composition of institutions that emerged during the Petrine reforms, while the country was continuously at war with Sweden and Ottoman Turkey. Without doubt, Kurs russkoi istorii is a better read and more incisive than his mentor's work. Nevertheless, we still find at least as many references to Soloviev in secondary literature. This proves K. A. Papmehl's claim that "a century later one rarely meets, in relevant historical literature, a reference to a source which has not been utilized, or at least mentioned by him." 18

Peter's creation of a modern army, his victory over Charles XII of Sweden, the founding of the Ruling Senate, the Holy Synod, and other state institutions and agencies were all phenomenal achievements in themselves. Briefly quoted in the epigraph, Lomonosov's treatment of Peter the Great is a witness to the great reformer's legacy in the pre-Catherinian period. Peter I remained as the central literary theme of Lomonosov's poems, odes, and orations during this period. Nicholas Riasanovsky suggests that "the index of a single volume of his collected works, the one covering poetry and orations, contains 267 page references to Peter I." Still, Lomonosov's appraisal of Peter I was simple and straightforward, as well as inclusive, and, certainly in line with his established image. ${ }^{19}$

Aside from his literary representations, the legacies of Peter the Great remained central in the official ideology and public thought of Catherinian

\footnotetext{
${ }^{15}$ Karamzin 1969, p.120 and passim.

${ }^{16}$ Soloviev 1981, xi.

${ }^{17}$ Vasilii Osipovich Klyuchevsky, Kurs russkoi istorii, Petrograd, 1918.

${ }^{18}$ Soloviev 1981, p.xiii.

${ }^{19}$ Riasanovsky 1985, p.31.
} 
Russia. Nor was his image substantially changed. It came to be linked, however, to the newly proclaimed glory of Catherine the Great. ${ }^{20}$ Without a proper understanding of the pre-Catherinian political culture, establishing the relationship between Russo-Turkish wars and Catherine's reforms would therefore be a futile venture.

\section{Enlightened Absolutism:}

On 28 June 1762, Peter III (Peter the Great's grandson) was deposed by a palace coup. His wife and successor, Catherine II (Yekaterina Alexeyevna), almost instantaneously released several manifestos, adding an even more fervent revolutionary spirit to the festival mood in the capital, where imperial regiments passed by the palace in her support. Catherine announced that Peter III was overthrown for threatening the institutions of state and society by passing arbitrary legislations and introducing alien customs. Catherine's supporters made further declarations to legitimate her claim to the throne. In Carol Leonard words, the coup d'etat of 1762, "with its Augustan imagery, gave to the victors an exhilarating experience with a mythic present."21

Scholars of $18^{\text {th }}$ century Russian history usually attribute very little, if any, role to Peter III's brief reign, which lasted for less than six months. Peter III typically appears as "brutish, stupid, and generally hopelessly inadequate as a person and as a ruler of Russia," merely contributing another chapter to the long narrative of Russia's deficient sovereigns that succeeded Peter the Great. Nicholas Riasanovksy, for instance, argues that if indeed the great reformer (Peter I) had been "looking down from on high, he had little reason to be joyful about his grandson." 22

Even though Peter III's reign has provoked almost no empirical research, and the record shows no evidence of an especially arbitrary rule, the overwhelming cult of Catherine's personality mechanically leads us to the conclusion that the natural foundation for the study of Enlightenment absolutism in Russia should begin with the latter. Carol Leonard, in her Reform and Regicide, eschews these notions and argues that the various manifestos issued by Catherine and her advisors during the immediate aftermath of the coup, have greatly influenced historians' perception of Peter III, and paved the way for a misleading representation of the coup as a genuine elite resistance to an excessively authoritarian regime. ${ }^{23}$

\footnotetext{
${ }^{20}$ Riasanovsky 1985, p.37.

${ }^{21}$ Leonard, 1993.

${ }^{22}$ Riasanovsky 1985, p.35.

${ }^{23}$ Leonard, 1993, p.1-10.
} 
Consecutively, the following era of liberalism under Catherine the Great has been viewed as a vehicle of political modernization. In Leonard's view, Peter III too closely adhered to the traditional legislative process engineered by his grandfather and took great interest in European liberal ideas. His reign was an astonishing achievement of the pre-Catherinian Enlightenment, and "a witness to the force of the Petrine imperial idea between 1725 and 1762." ${ }^{24}$ On the contrary, N. Riasanovksy adheres to Peter III's conventional image, and adds that Peter III followed Empress Elizabeth Petrovna (apparently quite sincerely) in emphasizing the direct link with Peter I and his absolute devotion to the person and policies of his ancestor, "even when his government was changing those policies." 25

Peter III bequeathed Catherine with a legacy of reforms that make the first years of her reign seem but a link in the chain between origins and outcomes. Catherine's rationalist vision seemed to reflect the underlying aspirations of most eighteenth century secular rulers in European: mobilization of the economy and expansion of the powers of the state, with awareness that this entailed increasing the ability of the population to pay taxes. In order to conclude the Petrine ecclesiastical reforms, Catherine transferred Church lands to the state (a process in fact Peter III had initiated earlier) and improved state revenues through eliminating overlapping functions between government institutions. She allowed the emancipation of nobles to remain in effect and used it as the basis for her later Charter of Nobility in 1785 and re-promulgated Peter's liberal commercial regulations.

In brief, over the course of one third of a century, something different and unexpected came about in Russia. Catherine II, a former German princess, new Russian Tsarina, without a legal claim to the crown and lacking strong connections or support, managed to rule the vast empire from 1762 to 1796 , expanding its borders to farther corners of Eurasia. For the first time since Peter the Great, a Russian monarch made a deep personal impress on the development of Russia, beyond the realm of economy and diplomacy, above the theatre of war, but more notably, on its intellectual and cultural evolution.

In the true sense of the word, Catherine II's enlightened absolutism emphasized Peter I's role as a reformer and benefactor of his subjects, who worked for their well-being, and for the common good. But at the same time she was quite impressed by his military successes on land and on water. Not surprisingly, the valuables captured from the Turks were brought to Peter the

\footnotetext{
${ }^{24}$ Leonard 1993, p. 3.

${ }^{25}$ Riasanovsky 1985, p.37.
} 
Great's tomb. It was especially during the Russo-Turkish War of 1768-1774, that the empress kept referring to her martial predecessor. ${ }^{26}$

One of the major problems that Catherine inherited from the post-Petrine period was Russia's formidable southern frontier, and the Crimean peninsula that rested on its tip. In common with most contemporary rulers, Catherine believed the conduct of foreign policy to be the true "métier de roi," (king craft) and from the onset of her reign she left her advisers in no doubt that she intended to take the decisions by herself. ${ }^{27}$ Catherine's solution to the Crimean problem therefore provides some indication of the future direction of her foreign policy, and of the high-handed manner of its execution.

From the Russian point of view, Ottoman control of the Crimea was at least a nuisance and often a danger for Muscovite security. The two mouths of the three most important rivers - the Don and the Dnepr - were located within the Crimean Khanate. More important, Tatar raiders made frequent incursions into lands claimed by Muscovy and carried off thousands of prisoners to be sold as slaves. It was embarrassing and frustrating for a state calling itself the Third Rome to be continuously humiliated by a Muslim neighbor, especially by a state, which was in theory an heir to the Mongol tradition. In the second half of the eighteenth century Catherine II pursued a policy of colonization of the southern Russian steppe-land almost reaching out to the northern Black Sea littoral. So long as the Crimea was under Ottoman control, she feared that such settlements would not be secure. Hence the Turkish declaration of war forced Catherine to the priorities re-assess to be given to her various projects.

On the question of Turkey's defeat and Russia's subsequent annexation of the Crimea, twentieth-century historians have not gone much beyond the works of V. D. Smirnov ${ }^{28}$ and İ. H. Uzunçarş1l1. ${ }^{29}$ One reason for this historiographical problem is that the Porte's late imperial frontiers policy has been ignored by historians to a greater extent than the study of the transformation of the Muscovite state into a far-flung multinational empire. The only recent contribution to our existing knowledge of the Turkish side of the story is Virginia Aksan's Ottoman Wars. ${ }^{30}$ Likewise, Alan Fisher, whose The Russian Annexation of the Crimea aged quite well in the field, suggests that from the Ottomans' perspective, the loss of Crimea with the Treaty of Küçük Kaynarca in 1774 was significant for both physical and psychological reasons. ${ }^{31}$

\footnotetext{
${ }^{26}$ Riasanovsky 1985 , p. 39.

${ }^{27}$ de Madariaga 1982, p.187.

${ }^{28}$ Smirnov 1887; Smirnov 1889.

${ }^{29}$ Uzunçarş1lı 1947; Karal 1962.

${ }^{30}$ Aksan 2007. Also see: Aksan 1993, p.221-238.

${ }^{31}$ Fisher 1970.
} 
Looking at some of the above mentioned sources it becomes possible to draw the following conclusions: In the midst if its so-called period of decline (or as more recently termed, period of transformation through traditional reform) and at a time when conventional means of securing military forces for the army had broken down entirely, the loss of Tatar military forces was crucial. Secondly, no longer could the Ottoman Empire expect a secure northern frontier, for the Russians were now en route to their soon-to-be-built Black Sea fleet. Thirdly, the Russians would now have an easier access to the Ottomans' Balkan provinces, and thus to Istanbul itself. And finally, from the psychological point of view, the loss of Crimea was important. While the Ottomans had been suffering defeats at the hands of the infidels for over a hundred years, Crimean Khanate was the largest Muslim province to be lost.

This last point deserves attention, as it will allow me to draw in some conclusions about the interconnectedness between wars and traditional reforms. Looking at the repercussions of 1774 in the late Ottoman Empire, it is possible to see a picture somewhat analogous to the Russian case. Reactions to the loss of Muslim Crimean Tatars caused a serious turmoil in the Sublime Porte, and led to the emergence of an incipient public sphere, critically debating and ultimately participating in decisions that affected the fate of the empire. The climate and articulation of reform within the Ottoman society therefore emerged after the Treaty of Küçük Kaynarca, particularly after the consciousness of defeat began troubling the public psyche. Once the new-Ottoman elites embraced defeat in Crimea, the prospect and reality of total collapse seemed as a problem that needs to be addressed through reason and secular means. What followed was the regulation or "regimentation" of army and society "as a result of (or as a prelude to) significant military reforms." 32 Thinking in broader terms, the outcome of consecutive defeats between 1774 and 1792 (Treaty of Yaş) was the bureaucratization, secularization and rationalization of the Ottoman Empire, from the Sultan down.

The affects of war on Catherine's internal policies had been at least as multifaceted. While Catherine's armies were winning glorious victories over the Turks, and her generals negotiating triumphant peace treaties, she faced the first blow that challenged her domestic authority. This was the Pugachevshchina (Pugachev Rebellion, or Cossack Insurrection), in which fifty or so peasant uprisings broke up between 1772-75, under the leadership of a Don Cossack named Emeliyan Pugachev. The Pugachev revolt dramatically brought the deficiencies of the Tsarist provincial administration to the forefront of Catherine's court. Despite the vast number of source material on the rebellion,

\footnotetext{
${ }^{32}$ Aksan 2007, p.180. Another useful source is Hanioğlu 2008.
} 
N. Dubrovin's Pugachev i ego soobshchniki is still the most comprehensive account of the crisis. ${ }^{33}$

In the narrow sense of the word, the immediate affect of the RussoTurkish war (rather, the peace treaty that concluded the war in 1774), was the breathing space it gave Catherine, which "released her mental energies from the task of prosecuting the war," enabling her to plan a reform of the local administration. ${ }^{34}$ Consequently, Catherine divided Russia into provinces and districts according to population statistics, granting each province an expanded administrative, police, and judicial apparatus. Despite the many loopholes in Catherine's new Statute, the complete remodeling of Russia's provincial administration was finished by 1775 . Isabel de Madariaga suggests that the inconsistencies in the implementation of the Statute of 1775, "by no means exhausted Catherine's reforming zeal," on the contrary, the existence of such problems were "inevitably the starting point for many of her later reforms." 35

Therefore the Police Ordinance of 1782, which provided the legal and constitutional framework for public order in the provinces, could be regarded as the continuation of Catherine's experiment with 'enlightened' administrative models for Russia. Likewise, Catherine's Charter to the Nobility (1785), which confirmed the liberation of the nobles from compulsory service, ultimately attempted to organize society into well-defined social groups, or estates, but in the end gave them personal rights that not even the autocracy could infringe. The Charter to the Towns that established self-government of the towns proved complicated and ultimately less successful than the one issued to the nobles. ${ }^{36}$ "In light of the French Revolution," Alexander Martin claims, "Catherine's Russia appeared as island of sanity and decency." Therefore her sudden death stunned people like Admiral Shishkov, whose "sun had been extinguished."37 Catherine's mild and glorious reign of thirty some years had calmed and pleased the Russian people so much that they somehow were all deceived by the illusion that her reign was "entrusted to some good and immortal divinity and would never end." ${ }^{38}$ Ideological transformation of the Russian society at the turn of the century happened so appallingly fast that the new outlook of the Russian public caught everyone by surprise.

In his Romantics, Reformers, Reactionaries, Martin skillfully conjures up the emotional watershed of the early 19th century in Russia. Francophobes and

\footnotetext{
${ }^{33}$ N.Dubrovin's Pugachev i ego soobshchniki, 3 Vols., St.Petersburg, 1884.

${ }^{34}$ de Madariaga 1982, p. 277.

${ }^{35}$ de Madariaga 1982, p.292.

${ }^{36}$ Acar, 2009, p. 198.

${ }^{37}$ Martin 1997, p.22.

${ }^{38}$ Martin 1997, p.22.
} 
Francophiles, romantic nationalists and disillusioned Catherinites all enter the stage at the turn of the century, and, even though, we know the fate of approaching Conservatism in Alexander I's Russia, we are still fascinated by their exciting yet frustrating experience that lead up to the Decembrist Uprising of 1825. Martin highlights a period that is largely neglected in the field since more scholarly attention had been lavished on the great Westernizer-Slavophile controversy of the $1830 \mathrm{~s}$. In other words, the first quarter of Russia's $19^{\text {th }}$ century had largely been ignored for its so-called lack of 'great thinkers.' Martin's account is therefore instrumental in highlighting the dilemmas that such popular conservative like N. M. Karamzin, S. N. Glinka, F. V. Rostopchin, A. S. Sturdza faced. The author successfully places them in their right historical context; the Napoleonic invasion if 1812 and Alexander's peculiar approach to reforming the autocracy. Taken together, Russia's conservative thinkers influenced and fueled the demand for radical change, which led to the culmination of the Decembrist uprising.

An instructive companion for readers of Alexander I's Russia (or for any part of the $19^{\text {th }}$ century) is Andrzej Walicki's History of Russian Thought. Walicki is convinced that Decembrists of the age of Alexander I never fully came to terms with the Petrine legacy. Therefore, their plans for political reform were, on the one hand, "imbued with the spirit of eighteenth century rationalism," but "showed the influence of the Romantic movement," on the other. ${ }^{39}$ In Walicki's view, rarely we find among conservatives, an awareness that principles of the Enlightenment were in fact incompatible with Romanticism. What developed, then, in Russia's intellectual sphere was the notion of a "conservative Russian exceptionalism," rooted in Karamzin's belief in autocracy, Shishkov's concern for Slavic identity, and Sturdza's defense of Orthodoxy. This anticipated "Orthodoxy, Autocracy, Nationality," the slogan to be coined by Uvarov, Nicholas I's education minister. ${ }^{40}$

With this brief synopsis of Russia's intellectual currents between 17921825 , the final part of this paper is divided into two parts, chronologically corresponding to the reigns of Nicholas I and Alexander II. I seek to reflect mainly on the existing historiography, to elucidate the relationship between the Crimean War and the ensuing period of Russia's Great Reforms (1855-1881).

\section{Contours of Russian Imperial Diplomacy:}

The Crimean War (1853-56) between Russia, Turkey, Britain, France and the Kingdom of Sardinia was the biggest international conflict of the European

\footnotetext{
${ }^{39}$ Walicki 1979, p.71.

${ }^{40}$ Martin 1997, p.206-207.
} 
powers in the century between the Napoleonic Wars and the World War I. The reasons behind this conflict are related to all the major political stress-points of $19^{\text {th }}$ century Europe: The Ottoman Empire, which seemed to be on the verge of collapse; Anglo-French imperial rivalry; the move for national selfdetermination in Italy against Austria; Russia's Mediterranean ambitions; and the struggle of all the imperial powers for influence over an unstable Middle East. Crimean War indeed offers a microcosm of 19th-century Great Power diplomacy itself.

A brief survey of the recent historiography on the Crimean War might shed some light on the international context of the Crimean War and the role Russian expansionism played in its outbreak. David Goldfrank, in his The Origins of the Crimean War (1994), admits that responsibility for the War lies decisively with the individual political leaders who could have prevented it, and that other economic factors such as the breakdown of the Concert of Europe after 1848 indeed created a climate favorable to the outbreak of an international conflict. ${ }^{41}$ Goldfrank also underscores Nicholas I's role in bogging Russia down in the controversy over the Christian subjects of the Ottoman Empire. For Goldfrank, Nicholas's insistence in the Palestine business appears to be the unnecessary. Likewise, Ann Pottinger Saab, in her The Origins of the Crimean Alliance (1977) argues that Napoleon III was interested in the war not so much for protecting the title of 'sovereign authority' in the Holy Lands, but particularly because he wanted to fend off the Russians from attacking the Ottomans. ${ }^{42}$ In a similar vein, Norman Rich, in his Why the Crimean War? (1990), suggests that Britain's main concern was to contain Russian expansionism. ${ }^{43}$ Paul Schroeder, in his Austria, Great Britain and the Crimean War (1973) also suggests that it was Nicholas I, who was at fault because he challenged France and Britain over something that ultimately Russia did not desperately need. ${ }^{44}$

Even though the above-cited works successfully place the Crimean War in its right international context, perhaps due to the authors' broader ambitions and agendas, they seem to underestimate the underlying motivations of the actual dramatis personae in this conflict - the Russian and Ottoman empires. They attribute Nicholas's attitude towards the Orthodox Christians in Turkey to the foreign policy designs of Sergei Uvarov's (minister of education) rubric of

\footnotetext{
${ }^{41}$ Goldfrank 1994.

42 Saab 1977.

43 Rich 1990.

${ }^{44}$ Schroeder 1973.
} 
'Official Nationality. ${ }^{45}$ For a better understanding of Russia's entanglement in the Crimean War we therefore need to turn to a different set of sources.

Nicholas Riasanovsky, in his Official Nationality in Russia, offers a more viable explanation. Riasanovsky argues that throughout the 1830s and 1840s Tsar Nicholas I "continuously refused to profit by unrest in Turkey, insisting that all subjects of the Sultan, regardless of religion or nationality, must obey their legitimate ruler." ${ }^{46}$ Even in the Danubian Principalities, which Russia probably could have annexed on more than one occasion, Riasanovsky suggests that Nicholas respected Turkish sovereignty. In brief, the conservative attitude of Nicholas I was largely led by legitimist concerns, which formed an integral part of his foreign policy. This, then, brings into mind the obvious question: When and how did Tsar Nicholas I resumed his predecessors' predatory policies towards the Sick Man of Europe?

Various hypotheses have been offered to explain this "striking turning point" of Russian policy in the Near East. For Riasanovsky least convincing is the claim that Nicholas I finally decided to side with the Pan-Slavists in 1854. Philip Moseley's Russian Diplomacy and the Opening of the Eastern Question in 1838 and 1839 (1934) advances the currently established assumption in the field. In 1838, Nicholas I believed that his forces were fully prepared to carry out a decisive military action in Turkey. But he also knew that occupation of the Straits, with or without the Sultan's consent would have certainly provoked a counter-offensive, both diplomatic and military, on the part of Britain and France. He therefore decided to diminish the danger of concerted action through playing on the many disagreements between Paris and London. ${ }^{47}$ Ultimately,

\footnotetext{
${ }^{45}$ This is a tri-partite formula (Orthodoxy, Autocracy, Nationality) designed as a new slogan for the development of Imperial Russia. These three terms became the main ingredients of a doctrine that dominated Emperor Nicholas I's reign. Scores of periodicals and books were published during Uvarov's term, aiming to propagate these three principles within the entire Russian school system. The idea was to sustain modernization in Russia without falling back on blind Europeanization efforts or revolutionary movements. The first component, Orthodox faith (pravoslavie), was instrumental in indoctrinating obedience to autocracy (the second principle), but also constituted the foundation of the Russian spiritual, ethical, and cultural life as a unifying factor in the nation. ${ }^{45}$ Absolutism (samoderzhavie) implied that Russia should avoid revolution through the enlightened leadership of a tsar. The third term in the tripartite formula (narodnost) was perhaps the most original, but also, the most ambiguous. Much like the public ambivalence towards Mahmud II and Abdülmecid's official nationality policies the broad idea of nationality had just become fashionable among the Russian intelligentsia, but there was no clear-cut definition for it. (Source: Whittaker 1984, chapter 6).

${ }^{46}$ Riasanovsky 1969, p.262.

${ }^{47}$ Moseley 1934, p.47.
} 
Nicholas got himself and the Russian diplomacy bogged down in the Eastern Question between 1839 and 1854.

Historians have long held that when Tsar Liberator, Alexander II, initiated his Great Reforms in the immediate aftermath of a war that displayed Russia's innate backwardness, it was already too late. Before looking at the Great Reform Era as largely a consequence of military defeat in 1856, we should first consider whether this last argument is actually valid. In his highly instrumental article on Nicholaen bureaucracy, Sidney Monas argues that "if it was Peter who shaved the beards, it was Nicholas who introduced the uniform and in general the standards of the military parade-ground, to the civil service." 48 Indeed, if we understand the process of bureaucratization in Russia the same way as Max Weber used the term Rationalisierung as a synonym for modernization, it implies Westernization, "with an attendant depersonalization of administration - uniformity, abstraction, a rationalized subordination and discipline. ${ }^{, 49}$ It therefore becomes possible to argue that Nicholas did not really fail to see the need for change or that he actually did probe the possibilities for major new developments in the realm of education, in the building of railroads, or in the modification and eventual abolition of serfdom. As Monas suggests, to all such enterprises, however, "Nicholas' Minister of Finance, the somber Count Kankrin, invariably replied that it could not be done, and Nicholas, although he disagreed with him and overruled Kankrin on a number of projects, in the long run, and basically, acquiesced. ${ }^{, 50}$

In a similar vein Walter Pinter suggests that the two major developments in Nicolas I's economic policy outside the agricultural area, monetary reform and railroad construction, oddly enough were undertaken with no intention of changing the general economic situation. The first was a technical problem and was carried out in a way that did not affect the total stock of money. The potentially momentous decision of beginning railroad constructions, on the other hand, was made on the narrowest fiscal grounds and almost nothing was said of its positive impact on the economy. ${ }^{51}$

Without doubt, when Alexander II assumed the throne in 1855, shortly after ending the Crimean War, he inherited a plethora of problems from Nicholas I's reign. Secondary literature on the Great Reforms is vast. Two books that stand out in an exponentially growing record of publications are

\footnotetext{
${ }^{48}$ Monas 1970, p.268-281; here, p.270.

${ }^{49}$ Monas 1970, p.269.

${ }^{50}$ Monas 1970, p.275.

${ }^{51}$ McKenzie Pinter 1967, p.253.
} 
Bruce W. Lincoln's In the Vanguard of Reform, and Ben Eklof's (et.al.) edited collection Russia's Great Reforms.

Lincoln's monograph ${ }^{52}$ almost instantly became a classic in the field. The main thesis of Lincoln's enlightened bureaucrats is that the pre-history of the Great Reforms during the reign of Nicholas I is a key to understanding the reforms themselves. Lincoln also argues that the enlightened bureaucrats have remained as a distinct minority at all times and that their success, both before and after 1855, depended upon a number of factors- experience, ideology, institutional position, support of the tsar etc. Lincoln's conclusions are quite revealing; he suggests that the enlightened bureaucrats ultimately "failed" because elements within autocracy were hostile to their efforts to renovate Russian political culture and institutions, and because the reformers were quickly removed from their power bases in key ministries.

A second useful source on Alexander II's reign is Ben Eklof's (et.al.) edited collection Russia's Great Reforms. ${ }^{53}$ Larissa Zakharova's Soviet 'revisionists', sets the tone in the opening paper: "Overcautious and contradictory from the outset, as soon as the reforms were enacted, they were snatched from the hands of their creators and delivered over to their enemies to be implemented." ${ }^{, 54}$ In consequence, many of the reforms represented less of a break with the past than appears at first sight. In the economy, for example, Peter Gatrell shows that diversification and development began well beforehand and continued afterwards: the decline of possessional factories, the increasing use of wage labor, the steady growth of cottage industry. In some respects the reforms actually impeded development, for example by imposing new economic burdens on the peasants, and by strengthening the administrative and economic role of the land commune. Nevertheless, the reforms did inaugurate a critical change in the attitude of the government, now more sensitive to the need for modern financial institutions, agrarian reform and railway construction.

Nevertheless, it was in the field of foreign policy, as W.E. Mosse pertinently described in his Alexander II and the Modernization of Russia, that in the latter years of his reign, Alexander II faced the greatest challenge. ${ }^{55}$ Tsar Liberator, as he was once called, Alexander II failed to control the more explosive forces in Russian society, which demanded further expansionism; the same forces Alexander himself had unleashed through his earlier reforms. In Mosse's words, "in his dealings with the representatives of Russian

\footnotetext{
${ }^{52}$ Lincoln 1982.

${ }^{53}$ Eklof 1994.

${ }^{54}$ Eklof 1994, p.32-33.

${ }^{55}$ Mosse 1958, p.119-124, and passim.
} 
expansionism showed in the fullest measure the ambiguity and weakness characteristics of so many of his undertakings."56 Essentially, the Tsar's approach to glitches in diplomacy and imperial security had been cautious and based on a predominant urge to avoid conflicts and wars. Since Russia needed a prolonged period to heal its wounds after the Crimean War, few were aware of this much needed recuperation period more than Alexander II. But this cautious policy failed to satisfy the ever-growing demand for expansionism in the critically debating public sphere.

As mentioned earlier, the outcome of the Russo-Turkish Wars between 1767 and 1790 was the emergence of a critically debating public sphere in the Ottoman Empire. I have also argued that this picture of the Ottoman society was analogous to their Russian counterparts (see page 11). Indeed, a similar situation occurred in Russia after 1856; the transformation of the Russian society until 1854, characterized by rapid urbanization and the emergence of literate masses, generated an unprecedented demand for continuous reforms. It was ultimately the emergence of a newspaper consuming public, which permanently altered the Russian printing industry, creating new genres for the different segments of the society. After 1856, these new trends coalesced into a body of what we may call the Russian public. The insularity of village life in Russia ceased with the gradual dissemination of popular printing products such as the boulevard press. Independent channels of knowledge production encouraged people to imagine themselves in relation to a larger world "and to ponder what it means to be Russian within that world." ${ }^{, 57}$

As Joseph Bradley suggests in his Muzhik and Muscovite, "like a prism that scatters rays of light, urbanization as an object of study reveals a broad spectrum of problems confronting a society in the process of modernization." 58 The gradual commoditization of newspapers through advertisements after 1856 was welcomed by a broader and much diverse group of clients, fundamentally changing the readers' roles in what could be termed as the Russian public. Ultimately, different newspapers with different audiences, positioned themselves on a wide array of ideological factions ranging from conservative to liberal.

In a similar vein, Daniel Brower suggests that the Russian national press "set ambitious cultural objectives, [and] offered an encapsulated version of a 'newsworthy' world that extended far beyond the mundane events and ordinary

\footnotetext{
${ }^{56}$ Mosse 1958, p. 119.

${ }^{57}$ Steinberg 1992, p.214.

${ }^{58}$ Bradley 1985, p.4.
} 
practices." 59 The emergence of a 'penny' or 'boulevard' press in Russia after 1856 was based on "the commercial formula of low prices, mass sales and advertising," and soon became a "key ingredient in setting the tone of public opinion." The Russian public opinion (obshcestvennost) was particularly shaped by the sensational journalism and Pan-Slavist propaganda of the boulevard press during the War against the Turks in 1877.

Jeffrey Brooks, in his When Russia Learned to Read, defines this new Russian public as a "more fluid society," which was an outcome of "the gradual erosion of pre-modern social and legal constraints including the division of the population into corporate groups, such as the gentry, clergy, merchants, lower middle classes (meshchanstvo) and the peasants. ${ }^{, 60}$ The inclusion of the meshchanstvo ultimately brought a new popular culture to the forefront of the Russian social life. Unlike the daily papers, which appealed to those with a more modern and cosmopolitan taste, the new popular reading materials soon became widespread in both villages and urban areas, securing a wider audience. Despite the abrasion of the dividing line between villages and urban centers, the Russian reading public was dichotomized within mutually excluding low and high cultures. In Brooks' words, "the appearance of the commercial literature signified a kind of cultural diversity that was new for Russia:" something, which the national press of the educated masses found difficult to absorb. ${ }^{61}$

Despite the gradual dissemination of commercial literature after the Crimean War, the so-called 'learned' or 'literary-political' journals managed to keep high subscription rates. They were able to so through debating and redefining popular notions of imperial unity as national unity. Therefore, I would argue that it is possible to see a Janus faced idea of nationalism in the minds of post-Crimean Russian columnists.

Dostoevskii's publisher, Mikhail Nikiforovich Katkov, belongs in this category. Shortly after the war in 1856 he founded the 'thick' journal Russkii Vestnik and, in 1863, became the editor of the widely circulated newspaper, Moskovskie Vedomosti. A highly interesting article by Andreas Renner discusses "why and by what means Katkov succeeded in redefining traditional imperial unity as national unity, albeit one yet to be achieved," and what exactly he meant when he evoked the idea of the Russian nation. ${ }^{62}$

\footnotetext{
${ }^{59}$ Brower 1990, p.170-171.

${ }^{60}$ Brooks 1985, p.xiii.

61 Brooks 1985, p.295. Jeffrey Brooks further suggests that the educated Russians, who condemned the popular commercial literature, actually "feared that it would hasten the deterioration in the values and character of the lower classes." (Source: Brooks 1985, p.291).

${ }^{62}$ Renner 2003, p.659.
} 
Renner argues that Katkov deserves renewed attention for several reasons; first and foremost, Katkov was "an ideologist of reformist autocracy" and "an advocate of modernization from above," during the reign of Tsar Alexander II. ${ }^{63}$ Renner further suggests that, far from supporting an aggressive or bigoted philosophy of political oppression, Katkov's nationalism was intrinsically linked to the reforms of Alexander II, which he had seen "as a blueprint for overcoming the backwardness laid bare by the Crimean War." ${ }^{\circ 4}$ The educated reader of the 1860 s should therefore recall the centrality of the nationality question in that remarkable decade, even though, after the Crimean War, some of the controversial issues faded against the expectation of reforms.

It is hardly coincidental that following the devastating defeat of 1856, what emerged was a quest for consolidating imperial power over the remote corners of the vast Russian Empire. Since the reign of Alexander II (1855-81) many politicians and intellectuals began to hope that Russia could be turned into a nation-state with a particular type of social, political, and, maybe, even cultural cohesion, rooted in a common historical experience of living together. Different policies aimed at integrating Russian and non-Russian into a single nation (edinyi narod) were proposed, of which cultural and administrative Russification was just one form of nation-building, based on an ethnic perception of national community. Nicholas Riasanovsky suggested that "the studies of non-Russian peoples of the Russian empire and of the relationship between these peoples and the Russians in the late imperial period" directly contributed to the development of the ideology of Eurasianism in the 1920s, which conceived of Russia-Eurasia as a separate world, neither European nor Asian. ${ }^{65}$

This last point relates closely to Dominic Lieven's hypothesis on late imperial Russia's peripherality concerns and attempts to preserve traditional supra-ethnic sources of identity and loyalty. Until the Crimean War, the Tsarist polity was more a dynastic and aristocratic empire than an ethnic Russian one, and "in some respects, the core Russian population was worse exploited than peripheral ethnic minorities." ${ }^{.66}$ The incorporation of non-Russian aristocracies into the Russian imperial elite, "whose own identity was in any case being transformed by Westernization," was a crucial element in the maintenance of the empire. Moreover, the regime never really had a strictly coherent nationality policy for dealing with the non-Russians. In Lieven's view, an empire that

\footnotetext{
${ }^{63}$ Renner 2003, p.660.

${ }^{64}$ Renner 2003, p.661.

${ }^{65}$ Riasanovsky 1972, p.29.

${ }^{66}$ Lieven 2006, p.20.
} 
attempts to govern "Balts, Kyrgyz and Ukranian in a similar fashion would not have lasted long."

\section{Conclusion}

With the annexation of Crimea in 1783 and subsequent Russian campaigns in the Caucasus and Central Asia, a Muslim question haunted the Tsarist regime by the middle of $19^{\text {th }}$ century. Evidently, Islam began to provoke certain anxieties among the Russian elites about political loyalty and social integration. Even conservative figures estimated a diverse population of some 20 million Muslim subjects, which was beyond the Ottomans' Muslim population. ${ }^{67}$ This situation made the Ottoman sultan a potential threat to the domestic order. In an era when the Ottoman sultan Abdulhamid II asserted himself as the caliph of all Muslims, the Ministry of the Interior in St. Petersburg warned local Russian police to monitor Muslim subjects for signs of sympathy with the "idea of a world-wide Muslim kingdom with the sultan at the head" and for evidence that they "pray for the former, and not for the Sovereign Emperor." ${ }^{68}$ Consequently, in late imperial Russia, a widespread fear of emerging nationalism of the minorities co-existed with the view that it did not pose any threat (even long-term) to the country's unity. ${ }^{69}$ The position which academic Orientalists started to advocate in the post-1856 period was in many ways similar to korenizatsiia, the policy of promoting indigenous cultures and elites, pursued by the Bolsheviks in the 1920s. ${ }^{70}$

The same argument could be made for contemporary Russia. There is a substantial amount of bewilderment amongst specialized western academics when it comes to adequately describing the Russian variant of imperialism. This problem contributes to the stereotype, still found in western literature, that the expansionism of the tsarist empire, much like Russia today, was due to a natural law of Russian history. As Dietrich Geyer points out, "the problem of imperialism gets lost in the old cliché about the Russians' unbridled drive to expand and dominate the world." ${ }^{, 71}$ Henry Kissinger's oft-cited theory of Russian expansionism (quoted in this paper's introduction) is a testimony to the ubiquitous misperception amongst even the most learned western observers. As the friction between the autocratic Russian Empire and the liberal European public opinion grew over the past two centuries, this misperception passed from

\footnotetext{
${ }^{67}$ McCarthy 1983.

${ }^{68}$ Crews 2006.

${ }^{69}$ Sanborn 2001, p.93-110; Weeks 1996; Geraci 2001.

${ }^{70}$ Tolz, 2005, p.143.

${ }^{71}$ Geyer 1988, p.5.
} 
generation to generation in such exaggerated forms as the growth of Russia "by ninety square kilometers per day since the time of Peter the Great." ${ }^{172}$

In retrospect, many historians and biographers of Russian monarchs unwittingly contributed to this misperception. Only a handful recognized that Peter I, Catherine II and Alexander II gradually came to terms with the problem of concurrently being absorbed by foreign affairs and domestic reforms. Robert Massie, the famous biographer of Peter the Great, belongs to that small group of historians. Massie argues that while the nature and sequence of Peter's early reforms were dictated by war and the need to finance campaigns, he quickly realized problems of micro-management without a boyar council as an autocrat. ${ }^{73}$ Hence came into being the modern Senate in 1711, on the eve of the disastrous Pruth Campaign, in order to deal with domestic reforms and administration. Likewise, Isabel de Madariaga, in her biography of Catherine II suggests that the success of the Russian Empress lies in her ability to separate the realms of civil government and the military. Even though, the separation between the civil and the military remained during the reigns of Paul and Alexander I, as Madariaga contends, the supremacy of the military over the civil ultimately revived and "gave its tone to Russian society, the paradomania which reached its apogee under Nicholas I., 74

With the advance of the $19^{\text {th }}$ century, the gap between Russia and the West grew larger, and the Russian autocracy took on a new form until the Crimean War, which made it clear that someone needed to readjust the intricate balance between the military and civil reforms. That someone was Alexander II, whose accession to the throne was a timely phenomenon, which probably gave the Russian autocracy a breathing space between 1855 and 1881. It is here that we come back to the oft-cited question: If the seeds of Russian autocracy's tragedy lay in the monarchs' inability to combine freedom and authority, can we say that the people's insatiable desire for expansion and military triumphs (a trait on which the monarchy legitimized its claim to rule) made Alexander II's reign almost insuperable? Overall, the reforms of Alexander II helped to assure Russia's survival as a major power after the disastrous Crimean War. Under Alexander II, the bounds of the empire were enlarged. In the words of W.E. Mosse, in Alexander II's reign, and in no small degree as the result of domestic reforms, "the Russian empire passed from the semi-feudal to the early capitalist stage of development," attaining a more assertive form of imperialism. ${ }^{75}$

\footnotetext{
${ }^{72}$ Y.v. Wartenburg quoted in Geyer 1988, p.6.

${ }^{73}$ Massie 1980, p. 748-749.

${ }^{74}$ de Madariaga 1981, p.588.

${ }^{75}$ Mosse 1958, p. 152.
} 


\section{BIBLIOGRAPHY}

Acar 2009

Aksan 2007

Aksan 1993

Bradley 1985

Brooks 1985

Brower 1990

Bushkovitch 2001

Bassin 2006

Cracraft 2003

Crews 2006

de Madariaga 1982

Dubrovin 1884

Eklof vd. 1994

Fisher 1970

Geraci 2001

Geyer 1988

Goldfrank 1994

Hanioğlu 2008

Hughes 1998
Kezban Acar, Rusya - Ortaçă̆'dan Sovyet Devrimine, İstanbul, İletişim Yayınları.

Virginia Aksan, Ottoman Wars, 1700-1870: An Empire Besieged, New York, Pearson.

V. Aksan, "The One-Eyed Fighting the Blind: Mobilization, Supply, and Command in the Russo-Turkish War of 17681774”, The International History Review, Vol.15, No.2, p.221-238.

Joseph Bradley, Muzhik and Muscovite Urbanization in Late Imperial Russia, Berkeley, University of California Press.

Jeffrey Brooks, When Russia Learned to Read: Literacy and Popular Literature, Princeton University Press.

Daniel Brower, The Russian City between Tradition and Modernity, 1850-1900, Berkeley, University of California Press.

Paul Bushkovitch, Peter the Great: The Struggle for Power, 1671-1725, Cambridge, Cambridge University Press.

Mark Bassin, "Geographies of Imperial Identity", in Cambridge History of Russia, Vol.2: Imperial Russia 1689-1917, ed., D. Lieven, New York, Cambridge University Press.

James Cracraft, The Revolution of Peter the Great, Massachusetts, Harvard University Press.

Robert Crews, For Prophet and Tsar: Islam and Empire in Russia and Central Asia, Mass, Harvard University Press.

Isabel de Madariaga, Russia in the Age of Catherine the Great, New Haven, Yale University Press.

N. Dubrovin, Pugachev $i$ ego soobshchniki, 3 vols., St.Petersburg.

Ben Eklof, John Bushnell and Larissa Zakharova, eds. Russia's Great Reforms 1855-1881, Bloomington, Indiana University Press.

Alan Fischer, The Russian Annexation of the Crimea, 17721783, New York, Cambridge University Press.

Robert Geraci, Window on the East: National and Imperial Identities in Late Tsarist Russia, Ithaca, Cornell University Press.

Dietrich Geyer, Russian Imperialism, 1860-1914, New Haven, Yale University Press.

David Goldfrank, The Origins of the Cold War, London, Longman.

Şükrü Hanioğlu, Brief History of the Ottoman Empire, Princeton, Princeton University Press.

Lindsey Hughes, Russia in the Age of Peter the Great, New Haven, Yale University Press. 
Karal 1962

Kissinger 1994

Klyuchevsky 1918

Leonard 1993

Lieven 2006

Lincoln 1982

Lomonosov 1952

Maikova 2004

Martin 1997

McCarthy 1983

Moseley 1934

Mosse 1958

Parker 1988

Pavlenko vd. 1973

Renner 2003

Riasanovsky 1985
Karamzin 1969

Enver Ziya Karal, Osmanl Tarihi, volumes v-viii, Ankara, Türk Tarih Kurumu Yayınları.

Nicholas Karamzin, Memoir on Ancient and Modern Russia (Zapiska o drevnei i novoi Rossii), Richard Pipes, ed., trans., New York, Atheneum.

Henry Kissinger, Diplomacy, New York, Simon and Schuster.

V. O. Klyuchevsky, Kurs russkoi istorii, Petrograd, 1918.

Carol Leonard, Reform and Regicide: The Reign of Peter III of Russia, Bloomington, Indiana University Press.

Dominic Lieven, "Russia as Empire and Periphery," in Cambridge History of Russia, Vol.2: Imperial Russia 16891917, ed., Dominic Lieven, New York, Cambridge University Press.

Bruce Lincoln, In the Vanguard of Reform: Russia's Enlightened Bureaucrats, 1825-1861, DeKalb, Northern Illinois University Press.

M. V. Lomonosov, Polnoe sobranie sochinenii, vol. VII, Trudy po filologii,1737-1758 gg., Moscow and Leningrad.

T.S. Maikova, Gistoriia Sveiskoi Voiny: Podennaia Zapiska Petra Velikogo, Krug.

Alexander Martin, Romantics, Reformers, Reactionaries: Russian Conservative Thought and Politics in the Reign of Alexander I, Dekalb, Northern Illinois University Press.

Justin McCarthy, Muslims and Minorities: The Population of Ottoman Anatolia and the End of the Empire, New York University Press.

McKenzie Pinter 1967 Walter McKenzie Pinter, Russian Economic Policy Under Nicholas I, Ithaca, Cornell University Press.

Sidney Monas, "Bureaucracy in Russia Under Nicholas I," in The Structure of Russian History: Interpretive Essays, ed., Michael Cherniavsky, New York, Random House.

Philip Moseley, Russian Diplomacy and the Opening of the Eastern Question in 1838 and 1839, New York, Russell.

W.E. Mosse, Alexander II and the Modernization of Russia, New York, Collier Books.

Geoffrey Parker, The Military Revolution: Military Innovation and the Rise of the West, Cambridge, Cambridge University Press.

N.I. Pavlenko, L.A. Nikiforov, and M.Ia. Volkov, eds. Rossiia $v$ period reform Petra I, Moscow.

Andreas Renner, "Defining a Russian Nation: Mikhail Katkov and the 'Invention' of National Politics," The Slavonic and East European Review, Vol.81, No.4, Oct., 2003, p.659-682.

Nicholas Riasanovsky, The Image of Peter the Great, Oxford 
Riasanovsky 1969.

Rich 1990

Roberts 1995

Saab 1977

Sanborn 2001

Schroeder 1973

Smirnov 1887

Smirnov 1889

Soloviev 1962

Soloviev 1981

Steinberg 1992

Tolz 2005

Uzunçarşıl1 1947

Walicki 1979

Weeks 1996
University Press.

N. Riasanovsky, Nicholas I and Official Nationality in Russia: 1825-1855, Berkeley, University of California Press.

Norman Rich, Why the Crimean War: A Cautionary Tale, McGraw-Hill.

Michael Roberts, "The Military Revolution, 1560-1660," in The Military Revolution Debate: Readings on the Military Transformation of Early Modern Europe, ed. Clifford J. Rogers. Boulder, Westview.

Ann Pottinger Saab, The Origins of the Crimean Alliance, Charlottesville, University of Virginia Press.

Joshua Sahborn, "Family, Fraternity, and Nation-building in Russia, 1905-1925," in R. Suny and T. Martin, eds., A State of Nations: Empire and Nation-Making in the Age of Lenin and Stalin, New York, p.93-110.

Paul Schroder, Austria, Great Britain and the Crimean War:

The Destruction of the European Concert, Ithaca, Cornel University Press.

V.D. Smirnov, Krymskoe Khanstvo pod verkhovenstvom Ottomanskoi Porty do nachala XVIII veka, St Petersburg.

V.D. Smirnov, Krymskoe Khanstvo pod verkhovenstvom Ottomanskoi Porty v XVIII stoletii, Odessa.

S. M. Soloviev, Istoriya Rossii s drevneishikh vremen, Vol. ixv, Moscow.

S. M. Soloviev, History of Russia: Peter the Great - The Great Reforms Begin, vol. XIX, ed. K.A. Papmehl, Gulf Breeze, Academic International Press.

Mark Steinberg, Moral Communities: The Culture of Class Relations in the Russian Printing Industry, 1867-1907, Berkeley: University of California Press.

Vera Tolz, "Orientalism, Nationalism and Ethnic Diversity in Late Imperial Russia," The Historical Journal, Vol.48, No.1, p. 127-150.

İ. Hakkı Uzunçarşılı, Osmanlı Tarihi i-iv, Ankara, Türk Tarih Kurumu Yayınları.

Andrzej Walicki, A History of Russian Thought: From the Enlightenment to Marxism trans., Hilda Andrews-Rusiecka, Stanford, Stanford University Press.

Theodore Weeks, Nation and State in Late Imperial Russia: Nationalism and Russification on the Western Frontier, 18631914, DeKalb. 
Whittaker 1984

Vucinich 1972
Cynthia Whittaker, The Origins of Modern Russian Education: An Intellectual Biography of Count Sergei Uvarov, 1786 1855, DeKalb, Northern Illinois University Press.

W. Vucinich, ed. Russia and Asia, Stanford. 